\title{
Kontroversi Doktrin Tarekat dalam Puisi Sufistik Karya Syaikh Isma'il al-Minangkabawi
}

\author{
Syofyan Hadi ${ }^{1}$
}

\begin{abstract}
Abstrak
Tarekat adalah gerakan dan aktifitas sufistik yang terwujud dalam bentuk lembaga dan organisasi. Sebagai sebuah organisasi keagamaan yang lebih berorientasi pada aktifitas menempuh perjalanan ruhaniyah dan spiritual, maka diperlukan adanya pemimpin, pembimbing ataupun penuntun yang akan mengantarkan para pengikut pada tujuan spiritual yang hendak dicapai. Dalam konteks inilah setiap ajaran tarekat berupaya merumuskan metode dan tata cara menempuh jalan yang hendak dilalui para salik termasuk kriteria para mursyid sebagai pemimpin dan penunjuk jalan tersebut. Hal ini jugalah yang coba dirumuskan Syaikh Isma'il alMinangkabawi dalam konsep-konsep tarekat Naqsyabandiyah Khalidiyah yang diajarkan dan dikembangkannya di Nusantara pada awal abad 19 M. Dalam konteks ajaran tarekatnya, Syaikh Isma'il al-Minangkabawi berupaya merumuskan beberapa aturan bagi para penempuh jalan ruhani menuju Tuhan (murid/salik) dan juga merumuskan kriteria pada pemandu jalan (syaikh/mursyid) yang berhak menjadi penuntun bagi para salik.
\end{abstract}

Kata Kunci: Kontroversi, doktrin, tarekat, sufistik, mursyid, rabitah, suluk.

\begin{abstract}
Tarekat is movement and activity sufistik embodied in institutions and organizations. As a religious organization that is more oriented to activities ruhaniyah and spiritual journey, it is necessary to have a leader, mentor, or a guide who will lead the followers of the spiritual goal to be achieved. In this context every teaching institute seeks to establish the method and procedure for the path to be traversed the salik including the criteria mursyid as leaders and guides them. It is also likely to try to formulate Shaykh Isma'il al-Minangkabawi in concepts congregation Naqsyabandiyah Khalidiyah taught and developed in the archipelago in the early 19th century $A D$ In the context of the doctrine congregation, Shaykh Isma'il al-Minangkabawi attempt to formulate some rules for facer spiritual path to God (pupil / salik) and also set the criteria on a guide (shaykh / mursyid) eligible to be a guide for the salik.
\end{abstract}

Keywords: Controversy, doctrine, congregations, Sufi, mursyid, Rabita, mysticism.

\footnotetext{
${ }^{1}$ Bahasa dan Sastra Arab Fakultas Adab dan Humaniora IAIN Imam Bonjol Padang.
} 


\section{A. Pendahuluan}

Sejarah mencatat bahwa hampir setiap ajaran dan doktrin sufistik yang diajarkan dan dikembangkan oleh seorang tokoh sufi sejak awal kemunculannya selalu mendapat kritikan dan penentangan dari banyak pihak terutama dari dalam Islam sendiri. Hal itu bisa dimaklumi karena beberapa ajaran dan doktrin sufistik seringkali dianggap menyimpang dari konsep ajaran yang dipegang oleh mayoritas umat Islam yang dalam prakteknya lebih banyak diikuti masyarakat muslim kebanyakan (awam). Sementara sufi adalah kelompok yang cenderung dalam posisi minoritas dengan kecenderungan menampilkan dan menghadirkan konsep atau praktek ritual ibadah yang terkadang berbeda dengan ajaran dan praktek kebanyakan umat Islam. Hal itu juga yang terjadi dengan ajaran, doktrin dan konsep sufistik yang dikembangkan oleh Syaikh Ismā‘îl al-Minangkabawī, khususnya dalam ajaran dan ritual amal tarekat Naqshabandiyah Khālidiyah yang dikembangkannya di Nusantara.

Beberapa konsep sufistik yang dirumuskan Syaikh Isma'il alMinangkabawi dalam doktrin ajaran tarekat Naqsyabandiyah Khalidiyah yang dikembangkananya di Nusantara, telah memunculkan beragam reaksi, penentangan hingga polemik hebat antara dirinya dan ulama-ulama Nusantara pada masanya termasuk dari ulama Timur Tengah. Adalah konsep sufistik seperti suluk dan ritual pengantin sufi, konsepi rabitah dan ubudiyah mursyid serta kensep karamah dan kemaksuman awliya' di antara doktrin sufistik syaikh Isma'il al-Minangkabawi yang mengundang polemik dan kontroversi para ulama di Nusantara pada awal abad $19 \mathrm{M}$.

Dalam konteks inilah, penulis ingin menghadirkan bentuk-bentuk konsep dan ajaran tarekat
Naqsyabandiyah yang dirumuskan Syaikh Isma'il al-Minangkabawi yang dinilai sebagian pihak mengundang polemik dan kontroversial di Nusantara atau bahkan dunia Islam. Walaupun boleh jadi kemunculan polemik dan penentangan terhadap konsep sufistik yang dirumuskannya di Nusanatara, lebih disebabkan faktor politis dan bukan dogmatis. Dalam makalah ini penulis akan menghadirkan konsep-konsep sufitik yang dianggap konteroversial tersebut dengan merujuk kepada dua buah naskah karangan Syaikh Isma'il alMinangkabawi sendiri. Adapun naskah pertama berjudul al-Manhal li-zikr alQalb yang ditulis pada tahun 1245 H/1811 M dan naskah kedua berjudul Nazm Syaikh Isma'il yang ditulis tahun 1270 H/1835 M. Kedua naskah masih dalam bentuk manuskrip yang disimpan pada koleksi pribadi. Terhadap kedua teks tersebut, penulis tidak akan menghadirkan suntingan teks seperti layaknya yang berlaku dalam studi filologi, karena itu telah penulis lakukan pada penelitian sebelumnya. Dalam tulisan ini penulis hanya akan mengelaborasi konsep ajaran tarekat yang dirumuskan Syikh Isma'il alMinangkabawi yang dianggap kontroversial dalam pandangan dogmatis formalitas ( $f i q h)$ dan juga dalam konteks tasawuf akhlaki di Nusantara.

\section{B. Riwayat Hidup dan Karya Syaikh Isma'il al-Minangkabawi}

Nama lengkapnya adalah Syaikh Ismā'̄̄l ibn 'Abd Allāh al-Khālidī alMinangkabawī al-Barūsī al-Jāwī. Syaikh Ismā'īl al-Minangkabawī dilahirkan di sebuah perkampungan kecil bernama Simabur di Pariangan Batu Sangkar Sumatera Barat. Syaikh Ismā‘̄il alMinangkabawī memulai pendidikannya dengan belajar mengaji atau membaca al-Qur'ān di bawah bimbingan ayahnya Abdullah yang juga merupakan salah 
seorang ulama di kampung Simabur. Di samping belajar al-Qur'ān, Syaikh Ismā‘îl al-Minangkabawī juga mempelajari kitab-kitab lainnya, seperti nahwu, șaraf, balāghah, mantiq, fiqh, kalām, tafsīr, hadīth di surau-surau yang ada di sana dan kepada beberapa ulama terkenal di kampungnya. ${ }^{2}$

Syaikh Isma'il tidak merasa cukup belajar di kampung halamannya, maka dia memutuskan untuk melanjutkan studinya ke tanah suci yang diantar langsung oleh ayahnya, karena memang usianya yang masih sangat kecil. $^{3}$ Dalam pengembaraan ilmiahnya inilah Syaikh Ismā'īl al-Minangkabawī menghabiskan umurnya selama 35 tahun untuk tinggal dan belajar di Tanah Suci. ${ }^{4}$ Di tanah suci Syaikh Ismā'̄̄l alMinangkabawī belajar kepada Syaikh Muhammad Șālih Ra'̄̄s al-Shāfi'‘̄, Syaikh 'Uthmān al-Dimyatī, Syaikh Aḥmad al-Dimyatī. Di samping itu, Syaikh Ismā'̄il al-Minangkabawi juga belajar kepada ulama-ulama terkenal lainnya di Makkah seperti Syaikh Muhammad Sa'īd ibn 'Alī al-Shāfi'ī alMakkī al-Qudsī. ${ }^{5}$

Dalam ilmu hakikat Syaikh Ismā‘n̄l belajar kepada Syaikh Ața‘illāh

\footnotetext{
${ }^{2}$ H.W. Muhd. Shaghir Abdullah, Syeikh Ismā 'ìl alMinangkabawi Penyiar Thariqat Naqsyabandiyah Khalidiyah (Solo: Ramadhani, $\mathrm{tt}), 13$.
}

3 ,Abdullāh Mirdad Abū al-Khayr, al-Mukhtașar min Kitāb Nashr al-Nūr wa al-Zuhār fi Tarājim Afāọil Makkah min al-Qarn al- 'Āshir ilā al-Qarn al-Rābi' 'Ashar (Jeddan: 'Alam al-Ma'rifah, 1986), 131.

4 M. Solihin, Melacak Pemikiran Tasawuf di Nusantara (Jakarta: Raja Grafindo Persada, 2005), 77.

5 Abū al-Fayḍ 'Abd al-Sattār ibn 'Abd al-Wahhāb al-Bakrī, Fayḍ al-Mālik al-Wahhāb al-Muta'āli bi Abnā'i Awā'il al-Qarn al-Thālith 'Ashar wa al-Tawāli Jilid 1 (Makkah al-Mukarramah: Maktabah al-Asadiyah, 2009), 924-925. Lihat juga 'Abdullāh Mirdad Abū al-Khayr, alMukhtașar min Kitāb Nashr, 132. ibn Aḥmad al-Azharī, Syaikh 'Abd Allāh al-Sharqawī, Syaikh Muhammad ibn 'Alī al-Shanawī, Syaikh 'Abd Allāh Afandi al-Arzinjan̄̄ dan Syaikh Khālid al-'Uthmānī al-Kurd̄̄. ${ }^{6}$ Syaikh Isma'il kemudian memperoleh kematangan spiritualnya di Jabal Qubays di Makkah. Hal dikarekan di Jabal Qubaislah Syaikh Ismā'īl al-Minangkabawī bersama sahabatnya Syaikh Sulaymān al-Qirimī dibai'at menjadi khalifah tarekat Naqshabandiyah Khālidiyah oleh Syaikh 'Abd Allāh Afandi al-Khālidī.' Selain itu, Syaikh Ismā‘n̄l al-Minangkabawī juga mengambil bai'at dan ijazah tarekat Naqshabandiyah Khālidiyah dari Syaikh Mawlānā Khālid al-Kurd̄̄ seperti dijelaskan sebelumnya. ${ }^{8}$

Setelah merasa cukup matang dalam hal intelektul dan spiritual, Syaikh Ismā'îl al-Minangkabawī memutuskan untuk kembali ke tanah air. Syaikh Ismā'îl al-Minangkabawī memilih Singapura sebagai tempat pertama yang disinggahi dan akhirnya memutuskan untuk menetap di sana dan mulai mengembangkan ajaran tarekat Naqshabandiyah. ${ }^{9}$ Dalam waktu yang

${ }^{6}$ Dua nama terakhir adalah tokoh ulama yang paling berpengaruh dalam karir syaikh Isma'il berikutnya sebagai tokoh pengembanag ajaran tarekat Naqsyabandiyah al-Khalidiyah. Oleh karena itulah, nama Syaikh Ismā'īl kemudian dinisbahkan dengan al-Khālidī yaitu nama sang guru Khālid al-Kurdī.

${ }^{7}$ Martin van Bruinessen, "After The Days of Abu Qubays : Indonesian Tranformations of The Naqsyabandyya-Khalidiya", Journal of The History of Sufism 5 (2007), 226-227.

${ }^{8}$ Muḥammad al-Amīn al-Khālidī, "Naskah Ajaran Tarekat Naqshabandiyah Khalidiyah", Koleksi surau Muhammad al-Amīn Kinali-Pasaman, 2122.

9 Adalah Syaikh Daud Sunur yang mendorong Syaikh Isma'il al-Minangkabawi untuk kembali ke Nusantara sekaligus memandunya hingga kemudian menetap di Singapura. Pilihan singapura sebagai tempat berda'wah didasarkan kepada situasi sosial, politik dan keberagamaan Minangkabau saat kepulangan syaikh Isma'il 
singkat, Syaikh Ismā'îl alMinangkabawi berhasil menarik simpati masyarakat dan akhirnya memiliki pengikut yang banyak di Singapura. ${ }^{10}$

yang tidak kondusif dan cenderung akan membahayakan keselamatan Syaikh Isma'il alMinangkabawi sebagai tokoh tarekat Naqsyabandiyah jika pulang ke kampung halamannya dan berdakwah di sana. Salah satunya adalah karena pada awal abad $19 \mathrm{M}$ itu kawasan pedalaman Minangkabau sedang dikuasai kelompok pembaharu (Padri) yang cenderung ekstrim dalam menegakan syari'at Islam termasuk menghukum pengikut tarekat sebagai bid'ah dan sesat. Lihat Michael Laffan, The Makings of Indonesian Islam: Orientalism and Narration of a Sufi Past (New Jersey: Princeton University Press, 2011), 43-44.

10 Singapura dipilih sebagai wilayah untuk berdomisili bagi Shaykh Ismā‘īl alMinangkabawī sekaligus mengembangkan ajaran tarekat Naqshabandiyah dan bukannya kembali ke kampung halamannya di Simabur Sumatera Barat juga memiliki alasan politis. Seperti yang diketahui bahwa semenjak awal abad $19 \mathrm{M}$, Pemerintah kolonial Belanda mengeluarkan edaran kepada semua gubernurnya untuk mengawasi secara ketat perkembangan dan pergerakan pengikut ajaran tarekat, terutama tarekat Naqshabandiyah. Nampaknya pemerintah Belanda telah mempelajari beberapa pemberontakan yang terjadi di beberapa wilayah lain di dunia bahwa kebanyakannya dimotori oleh kelompok-kelompok pengikut ajaran tarekat. Salah satunya seperti pemberontakan yang terjadi di Kaukasus Rusia awal abad 19 M yang berhasil mengusir penguasa Rusia dari kawasan tersebut. Lihat Alexander Knysh, "Sufism as an Explanatori Paradigm: The Issue of The Motivations of Sufi Resistance Movement in Western and Russian Scholarship, Journal of Die Welt des Islams, New Series, Vol. 2, Issue 2 (2002), 156. Lihat juga Moshe Gammer, "The Beginnings of The Naqshabandiyya in Dāghestān and The Russian Conquest of The Caucasus" Jornal of Die Welt des Islams, New Series, Vol. 34, Issue 2 (Nov 1994), 204-217. Lihat juga Michael Kemper, "Khalidiyah Networks in Daghestan and The Question Jihad, Jornal of Die Welt des Islams, New Series, Vol. 42, Issue 1 (2002), 41-47. Lihat juga Anzavur Demirpolat, "Sosio-Cultural Dynamics of Muridizm Movement in Caucasia, Journal of Ilahiyat Fakultesi Dergisi, 12:1 (2007), 24-37. Lihat juga Alexander Knysh, "Sufism as an
Kemasyhurannya di Singapura kemudian didengar oleh Yang Dipertuan Muda Raja 'Alī di Riau. Raja 'Alī pun mengirimkan utusan lengkap dengan perahu untuk bisa membujuk dan membwa Syaikh Ismā'îl alMinangkabawi ke kerajaan Riau. ${ }^{11}$

Syaikh Ismā'‘̄l al-Minangkabawī kemudian diangkat menjadi guru sekaligus penasehat spritual bagi keluarga besar istana kerajaan Riau Lingga di Pulau Penyengat. Selain menetap dan tinggal di kerajaan Riau Lingga, Syaikh Ismā'îl al-Minangkabawi juga mendatangi wilayah lain di semanjung Malaysia dan pernah menetap di sana beberapa waktu untuk mengembangkan ajaran tarekat Naqsyabandiyah Khalidiyah seperti di Pulau Penang, Negeri Kedah, Malaka dan Negeri Sembilan. ${ }^{12}$ Setelah sekian lama berkarir di Nusantara, Syaikh Ismā‘n̄l al-Minangkabawī akhirnya kembali ke Makkah dan menghabiskan sisa umurnya di sana sekaligus mengajar murid-murid dari Nusantara, khususnya yang berasal dari Minangkabau. ${ }^{13}$ Syaikh Ismā'îl al-Minangkabawī wafat di Jabal Qubays Makkah pada tahun 1275

Explanatory Paradigm: The Issue of The Motivations of Sufi Resistence Movements in Western and Russian Scholarship", Journal of Die Welt des Islams, New Series, Vol. 42, Issue 2 (2002), 162.

11 Martin Van Bruinessen, Tarekat Naqshabandiyah di Indonesia, Survey Historis Geografis dan Sosiologis (Bandung: Mizan, 1994), 99.

12 Bahkan disebutkan Shaykh Ismā‘̄il alMinangkabawī memiliki hubungan kekerabatan dengan penguasa kerajaan Negeri Sembilan. Wan Mohd. Shaghir Abdullah, Penjelasan Nazham Syair Shufi Syeikh Ahmad al-Fathani (Kulala Lumpur: Khazanah Fathiyah, 1993), 118-119.

13 Martin Van Bruinessen, Tarekat Naqshabandiyah di Indonesia, 100. 
H/1840 $\mathrm{M}^{14}$ dan dimakamkan di Ma'lah berdekatan dengan makam gurunya Syaikh Muhammad Șālih al-Ra'īs ibn Ibrāhīm yang wafat tahun 1240 $\mathrm{H} / 1806{ }^{15}$

Ada beberapa karya yang telah dihasilkan oleh Syaikh Ismā‘̄il al-Khālidī al-Minangkabawī semasa hidupnya. Diantaranya adalah: Pertama, kitab alManhal al-'adhbi li-dhikr al-qalb yang ditulis di Riau pada tahun 1245 H/1811 $\mathrm{M}^{16}$. Kedua, kitab Mawāhib rabb alfalaq yang selesai ditulis pada bulan Dhū al-Hijjah tahun 1268 H/ 1833 M di Teluk Belanga yaitu sebuah wilayah yang

${ }^{14}$ Tercatat dalam beberapa sumber, bahwa Shaykh Ismā'īl al-Khālidī al-Minangkabawī dan Shaykh Sulaymān al-Qirimī tidak hanya dibai'at dalam waktu yang bersamaan, keduanya pun meninggal dunia dalam waktu yang bersamaan pula di Jabal Qubays Makkah. Syaikh Sulayman al-Qirimī meninggal dunia pada hari Ahad tanggal 22 Dhū al-Hijjah tahun $1275 \mathrm{H}$, sementara Shaykh Ismā'̄il al-Minangkabawī meninggal pada hari Senin tanggal 23 Dhū al-Hijjah dengan perbedaan waktu kurang dari satu hari. Lihat. Muhammad Husayn ibn 'Abd al-Ṣamad alKhālidī, "Naskah Nahjat al-Sālikīn wa-Bahjat alMaslakīn," 21-22. Informasi yang sama juga ditemukan dalam. Muhammad al-Amīn alKhālidī, "Naskah Ajaran Tarekat Naqshabandiyah Khālidiyah,” 177-178. Sebagian sumber menyebutkan tahun $1280 \mathrm{H}$ seperti dalam 'Abdullah Mirdad Abū al-Khayr, alMukhtașar min Kitāb Nashr, 132.

${ }^{15}$ Abū al-Fayḍ 'Abd al-Sattār ibn 'Abd al-Wahhāb al-Bakrī, Fayḍ al-Mālik al-Wahhāb, 925.

16 Dalam konversi tahun 1245 H sebagai tahun penulisan naskah ini penulis revisi kembali konversi yang ada dalam tesis penulis yang berangka tahun 1829 M. Lihat Syofyan Hadi, Naskah al-Manhal al-'adhb li-dhikr al-qalb: Kajian atas Dinamika Perkembangan Ajaran Tarekat Naqshabandiyah al-Khâlidiyah di Minangkabau (Jakarta: Lembaga Studi Islam Progresif, 2010), 27. Penulis kemudian melakukan konversi ulang dengan menggunakan teori M.B.Lewis ternyata angka tahun $1245 \mathrm{H}$ jika dikonversi ke tahun Masehi adalah tahun 1811 M. Lihat teori konversi ini dalam Titik Pudjiastuti, Naskah dan Studi Naskah (Bogor: Akademia, 2006), 77-78. terletak di kawasan Pelabuhan Singapura. ${ }^{17}$ Ketiga, kitab al-Rahmah alhābițh fi dhikr ithm al-dhāt wa-alrābitah yang ditulis tahun 1269 H/1834 M. Keempat, kitab Nazam Syaikh Ismā 'ìl yang ditulis tahun $1270 \mathrm{H} / 1835 \mathrm{M}$. Kelima, kitab Kifāyat al-ghulām fì bayān arkān al-islām wa-shurūtih serta Risālat muqāranah 'urfiah wa-tauziah wakamāliah yang tidak diketahui tahun dan tempat penulisannya.

\section{Beberapa Konsep Sufistik Kontriversial dalam Ajaran Tarekat Naqsyabandiyah Khalidiyah.}

Seperti telah dijelaskan, terdapat beberapa bentuk ajaran dan doktirin tarekat syaikh Isma'il al-Minangkabawi yang dianggap kontroversi, sehingga mendapat banyak kritikan dan bahkan penentangan dari ulama Nusantara pada masanya. Di antara doktrin tersebut adalah;

\section{- Konsep Pengantin Sufi dalam Ritual Sulūk}

Adalah syaikh Isma'il alMinangkabawi yang pertama kali dalam karyanya menyebutkan istilah pengantin sufi (bikr) dalam konsep ajaran tarekat Naqsyabandiyah Khalidiyah. Syaikh Isma'il al-Minangkabawi menyebutkan para calon salik sebagai pengantin sufi (bikr) karena memang tata cara dan aturan yang dirumuskannya dalam ritual suluk yang mesti dijalankan seorang murid atau salik sangat identik dengan aturan yang berlaku pada pengantin wanita yang masih gadis dan perwan. Di

17 Informasi dari kolopon naskah ini dimana menyebutkan bahwa teks ini ditulis sendiri oleh Shaykh Ismā'îll al-Minangkabawī di Teluk Belanga Singapura menunjukan sekaligus mempertegas bukti bahwa memang Shaykh Ismā'îl al-Minangkabawī berdomisili di sana dan tidak pernah menetap di kampung halamannya Simabur Sumatera Barat. 
mana seorang gadis yang hendak naik pelaminan, harus mengikuti banyak ritual dengan segala syarat dan pantangan yang tidak boleh dilangar terutama dalam hal "pingitan" yang diberlakukan kepadanya. Hal demikian bisa dilihat dalam ungkapan berikut;

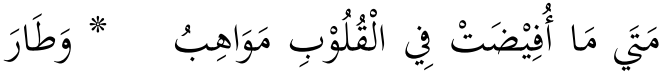

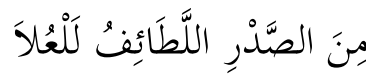

Selama dilimpahkan di dalam segala hati ini beberapa karunia* dan terbang daripada dada itu segala lațā'if bagi

Tuhan yang maha tinggi

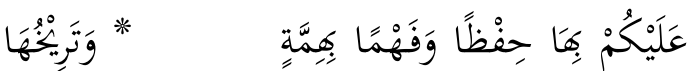

$$
\begin{aligned}
& \text { مُعْنِيْ وَمُعِيْنْ لِِمَنْ تَلاكَ }
\end{aligned}
$$

Lazimkan olehmu dangan dia itu mempahamkan dangan himmah* dan tarikhnya itu mengikuti lagi menolong

bagi siapa-siapa membaca akan dia

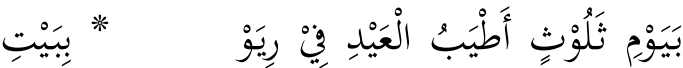

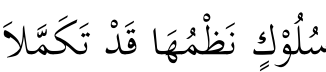

Pada hari Selasa sebaik-baik hari ia fitrah di dalam negeri Riau * di dalam rumah suluk nazamnya sungguhnya telah sempurna ia

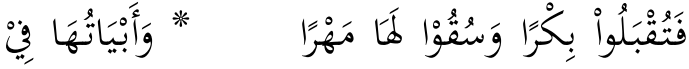

$$
\begin{aligned}
& \text { بَحَرِهَا طَعْمُهَا حَلاكَ }
\end{aligned}
$$

Maka terima oleh kami akan pengantin yang bikir dan hantarkan oleh kamu baginya isi kahwin* dan bilangan abyatnya di dalam lautannya itu rasanya

$$
\text { manis }{ }^{18}
$$

Dalam ajaran tarekat Naqshabandiyah yang dikembangkan oleh Syaikh Ismā'îl al-Minangkabawī ritual unik dan khusus yang menjadi karakter ajaran ini adalah ritual sulūk selama beberapa hari hingga 40 hari

\footnotetext{
${ }^{18}$ Naskah al-Manhal, 2.
}

lamanya. ${ }^{19}$ Perkataan sulūk secara harfiyah memiliki pengertian yang hampir sama dengan tarekat, keduanya sama berarti cara atau jalan untuk mencapai sesuatu. Dalam istilah tarekat Naqshabandiyah, ritual sulük kemudian dikenal sebagai cara atau jalan mendekati Allah swt guna memperoleh ma'rifat. Formatnya adalah dalam wujud kontempelasi dan latihan yang dilakukan dalam jangka waktu tertentu, seperti dalam waktu 10 hari, 20 hari dan waktu sulūk yang sempurna biasanya adalah 40 hari. ${ }^{20}$ Praktek sulūk pada prinsipnya adalah sama yaitu mengasingkan diri dari keramaian atau ke tempat yang terpencil. Dalam pengasingan diri dan kontempelasi tersebut seorang sālik melakukan zikir di bawah bimbingan seorang syaikh atau khalifahnya. Selama melakukan ritual sulük seorang sālik tidak boleh makan daging, kalaupun dibolehkan itupun hanya satu kali dalam 20 hari. Begitu juga dilarang bergaul dengan suami atau istri, makan dan minumnya diatur sedemikian rupa atau sesedikit mungkin. Begitu juga seorang sālik harus menyedikitkan tidur, berbicara, bahkan berkumpul dengan manusia. Waktu dan semua pikirannya sepenuhnya diarahkan untuk berpikir yang telah ditentukan oleh syaikh atau

${ }^{19}$ Bahkan karyanya berjudul al-Manhal al- 'Adhb li Dhikr al-Qalb ini ditulis dan diselaikan dalam masa sulūknya. Hal itu sebagainya terlihat dari salah satu bait di atas bi bayti sulūkin naẓmuhā

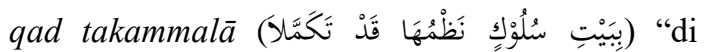
dalam rumah suluk nazamnya sungguhnya telah sempurna ia".

20 Aboebakar Atjeh, Pengantar ilmu Tarekat (Solo: CV. Ramadhani, 1985), 121-122. Lihat juga Martin van Bruinessen, Tarekat Naqsyabandiyah di Indonesia: Survei Historis, Geografis dan Sosiologis (Bandung: Mizan, 1992), 88. 
khalifah yang membimbing sang sālik selama kontempelasi tersebut. ${ }^{21}$

Ritual sulūk biasanya diadakan di sebuah bangunan khusus di mana rumah $s u l \bar{u} k$ ini biasanya bertingkat dua. Di lantai dua itulah si sālik akan melakukan ritual dengan ditutupi oleh kain tirai atau kain kelambu yang di dalamnya pengikut sulūk tidur. Ritual sulūk punya persyaratan yang cukup berat. Bagi peserta baru, dia harus ikut dan menjadi anggota tarekat terlebih dahulu melalui proses bai'at. Setelah itu sebelum memasuki ritual sulük akan ada sederet ritual lainnya. ${ }^{22}$

Seorang yang akan mengikuti ritual sulūk, harus terlebih dahulu bertobat dari segala dosa lahir dan dosa batin, serta mengakui sambil menyesali semua dosa yang telah dilakukannya. Karena itu dia harus berniat dengan ikhlas untuk melaksanakan sulūk semata-mata karena Allah, semata-mata mentaati perintah Allah dan Rasul-Nya, serta mengikuti petunjuk-petunjuk Syaikh mursyidnya selama ritual sulük nantinya. $^{23}$

Sebelum pelaksanaan sulük, seseorang itu harus mandi taubat dengan air yang bersih dengan berniat bahwa dia mandi taubat dari dosa lahir maupun batin karena Allah swt. Setelah mandi taubat hendaklah dia melaksanakan beberapa shalat sunat; yaitu shalat sunat wuḍū' 2 rakaat, shalat sunat taubat 2 rakaat, dan shalat sunat hajat untuk melaksanakan sulūk 2 rakaat. Setelah itu dia berniat sulūk menempuh jalan

\footnotetext{
${ }^{21}$ Muḥammad al-Amīn al-Khālidī, "Naskah Ajaran Tarekat Naqshabandiyah Khalidiyah" Koleksi surau Muhammad al-Amīn Kinali-Pasaman, 155157.

${ }^{22}$ Lihat lebih lanjut H.A.Fuad Sa'id, Hakikat Tarikat Naqshabandiyah (Jakarta: PT. al-Husna Zikra, 2001), 79-83.

${ }^{23}$ Khalifah Rajab al-Khalidi, Naskah Ilmu Segala Rahasia, 25
}

menuju kepada Tuhan Allah swt. dengan melaksanakan amal-amal sunnat seperti zikir, berdo'a, membaca al-Qur'ān dan sebagainya. $^{24}$

Setelah mandi dan melaksanakan serangkain shalat sunat serta menutupnya dengan shalat sunat taubat, seorang calon sālik diharuskan memakai kain kapan berwarna putih dan menghadap ke kiblat. Kemudian calon sālik masuk ritual bai'at dan duduk dengan duduk lawan duduk tawāru' shalat. ${ }^{25}$ Dalam kondisi seperti itu, maka seorang sālik kemudian menyerahkan dirinya kepada mursyid seperti halnya sesosok mayat di hadapan orang yang masih hidup dan inilah yang disebut talqin. Setelah menerima ba'iat dan talqin al-dhikr barulah seorang murid melakukan tawajjuh, räbițah, tawassul dan berikutnya dhikr. Talqīn al-dhikr atau bai'at al-dhikr dimulai dengan mandi taubat, ber-tawajjuh dan melakukan räbițah dan tawassul yaitu melakukan kontak (hubungan) dengan guru dengan cara membayangkan wajah guru yang men-talqīn (mengajari zikir) ketika akan memulai zikir. ${ }^{26}$

Selama sulūk berlangsung seorang sālik tidak boleh pulang ke rumahnya, termasuk saat sakit sekalipun. Akan tetapi, jika seorang sālik jatuh sakit, biasanya keluarga dari peserta sulük yang datang merawat dan ikut tinggal di sekitar rumah suluk. Untuk peserta yang pertama kali atau pemula

\footnotetext{
${ }^{24}$ H.A.Fuad Sa'id, Hakikat Tarikat Naqshabandiyah, 87-93.

25 Duduk tawāru' adalah duduk seperti duduk tahiyat al-ākhir dalam shalat, namun posisi miring tubuh yang berbeda. Di mana dalam duduk tawāru' sang sālik menghimpit kaki yang sebelah kanan sehingga tubuhnya miring ke kanan. Lihat Khalīfah Syaikh Ya'qāb, Naskah Ajaran Tarekat Naqshabandiyah Khalidiyah, 64.

${ }^{26}$ Lihat Jalāl al-Dīn, Rahasia Mutiara al-Ṭarīqah al-Naqshabandiyah (Bukittinggi, Partai Politik Tarekat Islam (PPTI), 1950), 6-7.
} 
dalam mengikuti ritual sulūk, dia juga tidak boleh menampakkan diri di muka umum. Jika dia hendak keluar untuk mandi ke sungai misalnya, maka kepala, tubuh dan wajah harus ditutupi kain agar tidak terlihat oleh orang lain. ${ }^{27}$

Selama sulūk dijalankan seorang sālik, juga tidak boleh memakan hewan bernyawa, seperti daging, ikan, ayam, termasuk telurnya. Makanan yang dibolehkan untuk murid yang mengikuti sulūk hanya makanan yang berasal tumbuh-tumbuhan seperti nasi dan sayuran. Hal itu disebabkan, terdapat pandangan dan keyakinan bahwa makanan yang bernyawa dianggap tidak baik dan berpeluang membuat hati sang salīk tidak khusu'. Sebab, makanan yang mengandung lemak hewani akan menyebabkan peningkatan aktifitas seksual dan nafsu shahwat seseorang. Kegiatan peserta sulūk biasanya dimulai dari shalat subuh, shalat taubat, berzikir dan seterusnya hingga zikir bersama. Pada malam hari serang sālik diharuskan mengikuti pelaksanaan shalat sunat tahajjud bersama mursid atau guru yang membimbingnya, serta memperbanyak ibadah tambahan dengan penuh kesungguhan dan kekhusukan. ${ }^{28}$

Murid atau sālik yang memasuki ritual sulūk inilah yang oleh Syaikh Ismā‘̄il al-Minangkabawī disebut dengan istilah pengantin sufi atau yang disebut bikr (بِكْرً) seperti dalam ungkapan $f a$ tuqbalū bikran wa suqū lahā mahran

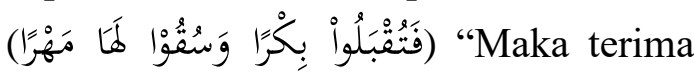
oleh kami akan pengantin yang bikir dan hantarkan oleh kamu baginya isi kahwin". Hal itu terlihat dalam aturan sulūk yang dirumuskan bahwa sang sālik harus diletakan di dalam kelambu khusus

\footnotetext{
${ }^{27}$ Khalifah Rajab al-Naqshabandiy, Naskah Ilmu Segala Rahasia, 27.

${ }^{28}$ Khalifah Rajab al-Naqshabandiy, Naskah Ilmu Segala Rahasia, 28.
}

untuk melakukan ritual. Di samping itu, sang sālik juga harus menjalani masa isolasi di mana dia tidak diperbolehkan keluar selama waktu yang ditentukan serta tidak boleh terlihat oleh orang lain termasuk pada saat dia keluar untuk keperluan yang bersifat darurat sekalipun diibaratkan seorang pengantin yang sedang berada dalam masa "pemingitan". Pengisolasian seorang sālik di dalam sebuah kamar dan bersunyi diri dalam kelambu juga ibarat pengantin di mana mereka bisa menikmati hubungan yang intim dengan pasangannya. Begitulah dengan ritual sulük, di mana sang pengantin sufi mengunci dirinya dalam kamar dan menutup dirinya dalam kelambu untuk bisa khusu' dan merasakan kenikmatan berhubungan dengan Allah swt.

\begin{tabular}{cccc}
\multicolumn{2}{c}{ Ritual ibadah } & seperti & yang \\
diajarkan & Syaikh & Ismā'îl al-
\end{tabular}
Minangkabawī seperti ritual sulūk tentu saja tidak bisa diterima oleh sebagian ulama terutama para fuqahā, ${ }^{29}$ Ritual ini

${ }^{29}$ Dalam konteks ini disebutkan banyak ulama dan fuqah' pada masa itu dan masa setelahnya menganggap ajaran tarekat Naqshabandiyah seperti sulūk ini sebagai bentuk ajaran yang bid'ah dan sesat. Lihat misalnya bagaimana ketika Shaykh Aḥmad Khatīb al-Minangkabawī menyerang ajaran tarekat Naqshabandiyah dalam kitabnya yang berjudul Ị̇hār zaghl al-kāzibīn fì tashabbuhihim bi-al-șādiqin (Menyatakan Kebohongan para pendusta dalam penyamaran mereka sebagai orang benar). Kemudian melalui kitabnya yang berjudul al-Āyāt al-bayyinah $l i-a l$ munșifin fì izālat khurafāt ba'ḍ al-muta șșibīn (Bukti-bukti yang nyata bagi orang-orang yang insaf dalam membasmi khurafat dan bid'ah orang-orang fanatik). Dan lihat pula bagaimana kemudian Shaykh Sa'ad Mungka kemudian membantahnya dengan mengarang kitab berjudul Irghām unūf al-muta 'annitīn fì inkārihim rābițah al-wāṣilīn (Menundukan hidung para penentang rābițah orang-orang yang sampai).dan juga kitabnya berjudul Tanbīh al 'awām 'alá taqrirāt ba'd al-anām (Peringatan orang awam terhadap putusan sebagian makhluk). Lihat. H.A. Fuad Said, Hakikat Tarekat Naqsyabandiyah (Jakarta: PT. al-Husna Zikra, 2001), 166-167. 
kemudian dianggap bid'ah dan menyesatkan, karena melakukan sesuatu yang tidak pernah dicontohkan oleh Rasulullah saw. ${ }^{30}$ hal inilah salah satuny ayang memicu terjadinya kontroversi dari sebagian ulama dan fuqaha terhadap ajaran tarekat Naqshabandiyah yang dikembangan Syaikh Ismā'îl alMinangkabawī.

\section{- Räbițah dan 'Ubūdiyah Murshīd}

Salah satu kekhususan ajaran
tarekat Naqshabandiyah yang
dikembangkan Syaikh Ismā‘n̄l alMinangkabawī adalah ajaran tentang rābitah (الرابطة). Rābiṭah pada intinya merupakan proses menghubungkan ruhaniah murid dengan ruhaniyah guru dengan cara menghadirkan rupa/wajah guru mursyid atau syaikh ke hati sanubari murid ketika berzikir atau beribadah. Tujuan daripada rābițah adalah agar sang murid atau sālik mendapatkan wasīlah (jalan/jembatan) dalam rangka perjalanan murid menuju Allah swt. ${ }^{31}$ Rābițah terhadap ruhaniyah mursyid yang kāmil mukammil diyakini akan bisa mengantarkan murid atau sang sālik menuju tangga mushādah ilahiyah melalui kekuatan dan kemulian serta derajat kewalian yang dimiliki syaikh mursyid yang kāmil mukammil ini.

\footnotetext{
${ }^{30}$ Bahkan penyesatan dan tuduhan bid'ah terhadap ajaran sulūk ini terus berlanjut hingga saat ini. Oleh karena itulah seorang tokoh tarekat Naqshabandiyah dari Sumatera Barat Shaykh Jalāl al-Dīn merasa berkepentingan menjelaskan praktek dan ritual sulūk tersebut kepada orangorang yang menentang karena ketidakpahamannya. Lihat Djalaluddin, Tiga Serangkai: Mengutuki Buku Fatwa Tharikat Naqsjabandijah \& Lima Serangkai Mentjari Allah dan Menemukan Allah Sesuai Dengan Intan Berlian/Lukluk dan Mardjan tharikat Naksjabanijah (Djakarta: Sinar Keemasan, 1964).

31 H.A. Fuad Said, Hakikat Tarekat Naqsyabandiyah, 71.
}

Selama rābițah seorang murid atau sālik diharuskan selalu menghadirkan syaikh rupa mursyid di hadapannya. Seorang murid mestilah selalu menghadapkan rohaninya kepada rohani syaikh yang kamil mukammil tersebut hingga memperoleh mushādah dengan Allah swt. $^{32}$

Ajaran rābitah ini didasari keyakinan bahwa pada ruhaniyah syaikh mursyid itu terdapat al-arwāh almuqaddasah Rasūlullah saw atau nūr Muhammad seperti dijelaskan dalam konsep al-fayd (emanasi) sebelumnya. Syaikh mursyid dianggap sebagai khalifah Allah swt. dan khalifah Rasūlullah saw. Mereka adalah wasīlah atau perantara yang mampu mengantarkan seorang murid menuju Allah swt. Jadi tujuan rābitah adalah memperoleh wasilah (jalan atau pengantar) menuju Allah yang Maha Suci. ${ }^{33}$ Ketika rābițah sudah mewarnai dan menjiwai seorang murid atau sālik, maka ia akan dapat melihat guru mursyidnya pada segala sesuatu, bahkan dalam setiap tarikan nafasnya. ${ }^{34}$

Dalam konteks ini, seorang murid harus menyerahkan dirinya secara total kepada sang guru mursyid. Seorang murid hendaklah menjadikan dirinya di hadapan sang mursyid ibarat mayat di tangan orang yang akan memandikannya

\footnotetext{
32 'Abd al-Majīd Muhammad AL-Khān̄̄ alKhālidī, al-Sa 'ādah al-Abadiyah fì Mā Jā'a bihi al-Naqshabandiyah (Dimashqa: Maṭba'ah alIṣlāḥ, 1313 H), 22.

33 Agus Sunyoto, Sulūk Abdul Jalil, Perjalanan Sufi Shaykh Siti Jenar Volume 2 (Yogyakarta: Pustaka Sastra Lkis, 2005), 255. lihat juga, Abu Bakar Aceh, Pengantar Ilmu Tarekat: Uraian Tentang Mystik (Solo: Ramadhani, 1986), 85-86.

${ }^{34}$ Mengenai pentingnya keberadaan murshid bagi seorang sālik lihat penjelasannya lebih jauh dalam. Seyyed Hossein Nasr, dkk, (Ed), Warisan Sufi, Warisan Sifisme Persia Abad Pertengahan (1150-1500)Jilid II (Depok: Pustaka Sufi, 2003), 539.
} 
atau ibarat bayi di tangan seorang ibu. Semua ini harus dilakukannya untuk memperoleh keberkatan sehingga sang mursyid bisa mengantarkannya ke hadapan Allah dengan kemulian dan karamah yang dimilikinya. ${ }^{35}$

Konsep rābițah inilah, yang kemudian juga memunculkan penentangan yang sengit dari kelompok atau pihak yang menuduh Syaikh Ismā'îl al-Minagkabawi $\overline{1}$ telah mengajarkan ajaran sesat. Salah satunya adalah konsep menyembah mursyid ('ubüdiyah mursyid) sebelum menyembah Allah swt. Dalam konsep ini diajarkan bahwa jika seorang murid belum bisa fokus kepada penghambaan kepada Allah swt, maka dia hendaklah menghadapkan penghambaan itu kepada guru mursyid terlebih dahulu. Seperti dalam bait berikut.

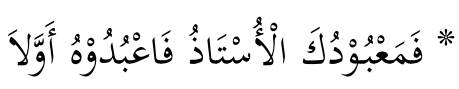

Dan sungguh telah dikata orang manakala adalah matamu itu juling* maka $m a$ 'būdmu itu ialah gurumu jua maka sembah olehmu akan mula-mula

إلِّ

$$
\begin{aligned}
& \text { هَذَا يُسَمَّي ذِكْرَ رَابِطَة وَهِيَ }
\end{aligned}
$$

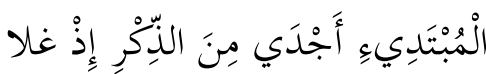

Barmula itulah yang dinamai akan zikir rābițah dan yaitu*

kepada mula-mula terlibih memeri faedah daripada zikir karana telah mahal ia itu ${ }^{36}$

Dalam bait-bait di atas Syaikh Ismā'‘̄l al-Minangkabawī menjelaskan bahwa rabitah diperlukan manakala seorang murid atau salik yang masih berada dalam tingkat pemula mengalami kesulitan untuk fokus dalam

\footnotetext{
35 'Abdullāh ibn 'Alawī al-Haddād al-Haḍramī, Risālah Adab Sulūk al-Murid (al-Qāhirah: Dār al-Ḥāwī li al-Ṭibā'ah wa al-Nashr, 1994), 54-55.

${ }^{36}$ Naskah al-Manhal, 19.
}

penghambaan kepada Allah swt. Di mana mata hati dan fikirannya masih dicampuri dengan sesutau yang lain selain Allah swt sebagaimana dalam ungkapan wa qad qīla mahma kāna 'aynuka ihwwalā ( وَقَدْ قِيْلَ مَهْمَا كَانَ عَيْنُكَ (إحْوَالًا manakala adalah matamu itu juling". Maka dalam kondisi seperti ini, untuk membantu fokus sang murid maka hendaklah dia menghadapkan penyembahan kepada Tuhan itu dengan terlebih dahulu menghadapkannya kepada rohani guru mursyidnya. Dengan demikian guru mursyid akan membantu fokus penyembahan dan mengantarkannya kepada penyembahan kepada Allah swt. Menjadikan rohani guru mursyid demi tercapainya fokus penyembahan seorang murid pemula inilah yang disebut dengan rābițah, sebagaimana terlihat dalam ungkapan hādha yusammā dhikr rābițah wa hiya ilā al-mubtadi' ajdā (هَذَا يُسَمَّي ذِذْرَ رَابِطَةٍ Barmula itulah yang dinamai akan zikir rābițah dan yaitu, kepada mula-mula terlibih memeri faedah".

Konsep rābitah inilah yang kemudian membuat banyak ulama pada zamannya menuduh Syaikh Ismā‘̄il alMinangkabaw $\overline{1}$ telah menyebarkan kesesatan. Ungkapan pada fa ma 'būduka al-ustādh fa'budūhu awwalā ( فَمَعْبُوْدُكَ (الْأُسْنَاذْ فَاعْبُدُوْهُ أَوَّلاً ialah gurumu jua maka sembah olehmu akan mula-mula" adalah sesuatu yang sulit untuk dijelaskan. Andaikata Syaikh Ismā' $\overline{1}$ al-Minangkabaw $\overline{1}$ mampu memberikan penjelasan terhadapnya, maka tentu saja penjelasannya akan sangat sulit diterima dan dimengerti oleh kebanyakan umat Islam. Sehingga, muncullah tuduhan kesesatan dan 
kemusyrikan terhadap ajaran rābițah ini dari beberapa pihak dan ulama pada zamannya. ${ }^{37}$ Tuduhan itu salah satunya pernah dikemukan oleh Shayk Sālim bin Samīr al-Hadramī salah seorang ulama asal Hadramaut yang pernah berdakwah di Nusantara pada saat bersamaan dengan Syaikh Ismā'īl alMinangkabawī. ${ }^{38}$ Dalam teks al-Manhal Syaikh Ismā‘̄ill al-Minangkabawī menyebutkan sang pengkritik ini sebagai orang bodoh yang tidak bisa mengerti hakikat ajaran tarekat yang diajarkannya. Kebodoohan dan kegelapan hatinya pun bertambah disebabkan rasa iri dan dengki kepada Syaikh Ismā'īl alMinangkabawi $\overline{1}$ sehingga dia telah mengingkari ajaran rabitah yang diajarkannya. Sebagaimna terlihat dalam salah satu baitnya. ${ }^{39}$

${ }^{37}$ Dalam konteks rābițah ini Shaykh Muhammad Amīn al Kurdī telah memberikan penjelasan tentang wajibnya seorang murid terus-menerus me-rābitah-kan ruhaniyahnya kepada ruhaniyah shaykh murshid, guna mendapatkan limpahan karunia (al-fayd) dari Allah swt. Dalam penjelasanya, al-Kurdī menegaskan bahwa karunia yang didapati itu bukanlah karunia dari murshid, sebab murshid tidak bisa memberi bekas atau pengaruh apapun. Hanya Allah swt semata yang bisa memberi bekas, karena di tangan Allah swt sajalah seluruh perbendaharaan yang ada di langit dan di bumi. Hanya saja Allah swt memberikan kelimpahan-Nya, melalui pintupintu atau corong-corong yang telah dipilih dan ditetapkan-Nya sendiri. Di antara corong-corong Tuhan itu adalah para kekasih-Nya yaitu para para wali Allah swt yang mampu memberikan shafa 'at dengan izin-Nya. Muhammad Amīn alKurdī, Tanwīr al-Qulūb fì Mu'āmalat 'Allām alGhuyūb (Jeddah: al-Ḥarām ain, tt), 448. Lihat juga Syofyan Hadi, Naskah al-Manhal al- 'Adhb li Dhikr al-Qalb: Kajian atas Dinamika Ajaran Tarekat NAqshabandiyah Khalidiyah di Minangkabau (Jakarta: Lembaga Studi Islam Progresif (LSIP), 2011), 47.

${ }^{38}$ Azyumardi Azra, Islam Nusantara, Jaringan Global dan Lokal (Bandung: Mizan, 2002), 41 dan 141. Lihat juga B.J.O Schrieke, Pergolakan Agama di Sumatera Barat; Sebuah Sumbangan Bibliografi (Jakarta: Bharatara, 1973), 28.

${ }^{39}$ Naskah al-Manhal, 43.
- Konsep Wālī dan Karāmah Awliyā'

Dalam ajaran tarekat Naqshabandiyah Khalidiyah, seperti telah dijelaskan bahwa guru dianggap sebagai sosok yang bisa mengantarkan seorang murid berhubungan dengan Allah swt karena cahaya kewalian yang mereka miliki. Kewaliaan mursyid inilah yang ditolak oleh sebagian ulama yang anti tasawuf atau mereka yang memahami tasawuf dengan cara-cara individual. $^{40}$ Mereka yang menjalani praktek tasawuf secara individual merasa mampu menembus jalan ruhani yang penuh dengan rahasia menurut metode dan cara mereka sendiri tanpa bantuan siapapaun termasuk syaikh mursyid yang sudah wali sekalipun. Dengan mengandalkan ibadah dan latihan rohani berdasarkan pengetahuan yang selama ini mereka dapatkan dari ajaran alQur'an dan Sunnah, mereka merasa yakin bisa menghubungkan diri dengan Allah swt tanpa bantuan atau perantara rohani orang lain. ${ }^{41}$

Dalam perjalanan spiritual para sufi, banyak tokoh sufi yang kemudian memang mengakui bahwa dalam praktek sufisme, hampir bisa dipastikan seorang yang melakukan perjalanan spritual tanpa bimbingan seorang mursyid hanya akan meraih kegagalan spiritual. Banyak

40 Shah Ismā'îl ketika naik tahta di kerajaan Safawiyah, bukan hanya menganggap karāmah dan wilāyah yang dimiliki para murshid tarekat itu palsu, namun dia juga memerintahkan pengikutnya untuk membunuh semua murshid tarekat yang dianggap wali oleh para pengikutnya. Agus Sunyoto, Retno Suffatni, Sulūk Malang Sungsang: Konflik dan Penyimpangan Ajaran Syaikh Siti Jenar (Yogyakarta: LKiS Pelangi Aksara, 2004), 252.

${ }^{41}$ Seyyed Hossein Nasr, The Garden of Truth: The Vision and Promise of Sufism, Islam's Mystical Tradition, diterjenahkan oleh Yuliani Liputto, The Garden of Truth: Mereguk Sari Tasawuf (Bandung: PT. Mizan Pustaka, 2010), 17. 
ulama dan juga para sufi yang terbukti mengalami kegagalan spritual ketika mereka mencoba menempuh jalan sufi dalam rangka menemukan Tuhan tanpa menggunakan bimbingan mursyid. Ibn 'Ața'illāh al-Sakandarī misalnya adalah satu satu tokoh sufi yang pada awalnya tidak mengakui peran seorang mursyid sebagai mediator untuk mengantarkan seorang murid kepada Allah dan diapun memilih jalan sufi sendiri. Akan tetapi, akhirnya dia harus menyerah dan harus mengakui bahwa pada kenyataannya dalam proses menuju Allah swt tetap membutuhkan peran dan campur tangan seorang mursyid yang bertugas menjadi mediator dan pengantar seorang sālik mencapai hakikat Allah swt. ${ }^{42}$

Tidak sedikit ulama terkemuka dan tokoh sufi besar yang memberikan pengakuan bahwa seorang dengan kehebatan ilmu agamanya, belum tentu akan mampu menempuh jalan sufi kecuali atas bimbingan seorang syaikh atau guru mursyid. Bahkan, seorang yang sudah disebut alim sendiri tetap membutuhkan seorang pembimbing ruhani, walaupun secara lahiriah pengetahuan yang dimiliki oleh sang alim tersebut lebih tinggi dibanding sang mursyid itu sendiri. ${ }^{43}$ Karena belum

42 Ibn 'Aț̄â'illāh al-Sakandarī, al-Hikam (Mișr: Maktabah wa-Maṭba'ah Muḥammad 'Alī Șābih wa-Awlādih, tt), 29-30.

43 Belakangan muncul fenoma Tuangku Shaykh Muhammad Ali Hanfiyah dari Solok Sumatera Barat sebagai murshid tarekat Qadiriyah Hanafiyah dan sekaligus juga menguasai ajaran tarekat Naqshabandiyah dan Aliwiyah. Dalam usianya yang relatif sangat muda, ternyata dia memiliki pengikut yang cukup banyak dari kalangan para shaykh dan kiyai, para ulama, akademisi hingga intelektual muslim di Indonesia yang memiliki gelar doktor dan profesor. Secara keilmuan dan pendidikan tentu saja Shaykh Tuangku Muhammad Ali Hanfiyah kemungkinan besar masih jauh tertinggal dibandingkan dengan sebagian muridnya itu. Namun, secara spritualitas Tuangku Shaykh Muhammad Ali Hanfiyah diyakini oleh tentu soal hubungan yang bersifat spritulitas atau soal-soal batiniyah, seorang yang berprediket alim tidak lebih menguasainya dari seorang mursyid yang sudah diakui tingkat ubudiyahnya atau yang disebut dengan istilah murshīd yang 'ábid. ${ }^{44}$

Tentu saja tidak semua yang disebut mursyid bisa mengantarkan muridnya mencapai hakikat Allah swt. Hanyalah mursyid yang sudah mencapai tingkat kāmil mukammil seperti dijelaskan sebelumnya. ${ }^{45}$ Mursyid tipikal seperti ini dianggap seorang yang telah mencapai derajat keparipurnaan ma'rifatullāh sebagai insan yang kāmil. Dia sudah dipercaya bisa memberikan bimbingan jalan keparipurnaan bagi para pengikut atau murid-muridnya. Sosok mursyid seperti inilah yang disebut dengan syaikh atau guru mursyid yang diyakini sudah memiliki atau berada dalam taraf kewalian. Merekalah yang

muridnya lebih tinggi sehingga mereka munundukan rohani kepada sang Tuangku yang masih berumur sangat muda untuk bisa diantarkan menuju Allah swt melalui ritual zikir yang diajarkan dan dituntunkan kepada para muridnya. Lihat Tim Redaksi Majalah Detik, "Sufi Metropolis", Majalah Detik, Edisi 89 (1218 Agustus, 2013), 45.

44 Kisah bergurunya nabi Musa as. kepada nabi Khiḍr as. adalah bukti betapa seorang yang walaupun 'ālim, namun tetap butuh bantuan seorang murshid guna menyelami hikmah ma'rifatullāh. Nabi Musa as. secara lahiriyah ilmunya tentu lebih sempurna dari nabi Khiḍr as. karena dia menerima wahyu dari Allah swt. berupa hukum-hukum shari'at yang kemudian tertuangkan dalam kitab Taurat. Akan tetapi, dalam hal ilmu batin dan hikmah nabi Khiḍr ternyata lebih unggul daripada Musa as, karena dia memiliki ketajaman mata batin yang tidak dimiliki nabi Musa as. lihat kisanya dalam surat al-Kahfi [18]: 60-82.

45 Muhammad Amīn al-Kurdī memberikan dua puluh empat syarat minimal seorang guru mushid bisa disebut shaykh yang kämil mukammil. Lihat Muḥammad Amīn al-Kurdī, Tanwīr al-Qulūb fì Mu'āmalat 'Allām al-Ghuyūb (Jeddah: al-Harām ain, $\mathrm{tt})$, 525-527. 
kemudian dianggap dan diyakini sebagai waliyullah yang bukan saja ahli ilmu namun juga ahli hakikat dan ma'rifat. ${ }^{46}$ Mereka adalah para kekasih Allah swt yang senantiasa total dalam ketaatn dan 'ubudiyah kepada-Nya, dan tidak sedikitpun menyempatkan dirinya terjerumus dalam lembah dan lumpur dosa dan kemaksiatan kepada Allah swt. ${ }^{47}$

Pembicaraan tentang kewalian (wilāyah) dalam teks al-Manhal seperti dalam kutipan berikut.

$$
\begin{aligned}
& \text { * } \\
& \text { دَائرَةُ الُُْجُوْبِ وَهِيَ كِنَايَةُ }
\end{aligned}
$$

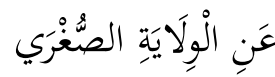

Dāirah al-wujūb itu dan yaitu kinayah * daripada al-wilāyah yang kecil.

$$
\begin{aligned}
& \text { مَقَامُ هُنَا يُسَمَّي بِدَائرَةِ الْوُجُوْبِ }
\end{aligned}
$$

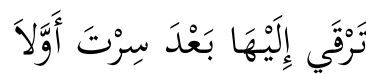

Adalah satu maqam disini dinamai akan dia dangan dāirah al-wujūb * yang naik engkau kepadanya kemudian daripada

berjalan engkau mula-mula

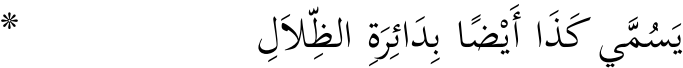

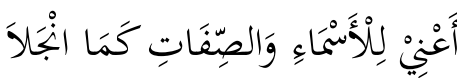

Dinamai akan dia pula dangan dairah segala bayang-bayang* artinya bagi segala asma' dan segala sifat seperti yang telah nyata ia

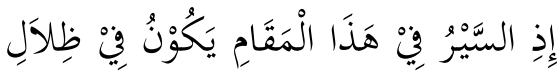

$$
\begin{aligned}
& \text { * الََْسمَاءِ وَالصِّفَاتِ لِنِيْ الْعُلاً }
\end{aligned}
$$

Karana perjalanan pada maqam ini ada ia di dalam bayang-bayang* segala asma' dan segala sifat bagi Tuhan Yang Maha Tinggi

\footnotetext{
46 ‘Abdullāh Aḥmad ibn 'Ajībah, Mi 'rāj alTashawwuf ilā Haqā'iq al-Tașawwuf (alMaghribī: Dār al-Bayḍā', tt),79.

47 Syofyan Hadi, Naskah al-Manhal al-'Adhb li Dhikr al-Qalb, 59.
}

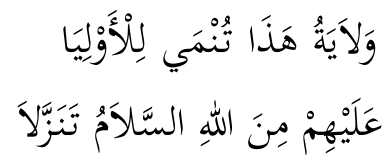

Barmula walāyah perjalanan ini dibangsakan akan dia bagi segala auliy $\bar{a}^{*} *$

yang atas mereka itu daripada Allah ta 'âlá salam yang turun ia

$$
\begin{aligned}
& \text { وَشُغْلُكَكَ فِيْ هَذَا مُرَافَبَةُ الْمَعِيَّةِ }
\end{aligned}
$$

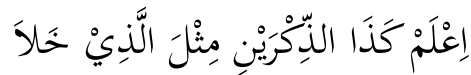

Dan syughulmu pada ini ialah murāqabah ma'iyah jua*

ketahui olehmu demikian lagi yang dua zikir itu seperti yang telah lalu juga

$$
\begin{aligned}
& \text { كَذَا يَنْفَعُ التَهْلِيْلُ فِيْهَا لِسَالِلكِ } \\
& \text { بإِحْضَارِ مَعْنَاهُ لِقَلْبِ تَعَقَّلَاك }
\end{aligned}
$$

Demikian lagi manfaat tahlīl lisān padanya itu bagi yang sālik itu* dangan menghadirkan ma'nanya bagi hati yang meakali ia akan dia. ${ }^{48}$

Pada bait-bait di atas, Syaikh Ismā'‘̂l al-Minangkabawī membicarakan tentang kewalian (الْأَوِْْيَا), dipersepsikan sebagai manusia yang sudah mendapat keutamaan dan kemulian dar Allah swt. Keutamaan yang diberikan Allah swt tersebut berupa puncak ketenangan dan kedamian dalam diri mereka, seperti dalam ungkapan 'alayhim minallāh al-salām tanazzalā “yang atas mereka itu daripada Allah ta 'álá salam yang turun ia". Namun, kewalian yang disebutkan Syaikh Ismā'īl alMinangkabawī adalah kewalian yang paling rendah atau yang disebut dengan

\footnotetext{
${ }^{48}$ Naskah al-Manhal, 23.

49 Lihat penjelasan tentang kewalian dan pembagiannya dalam Diyā' al-Dīn Aḥmad Mușțafá al-Khamashkhanawī al-Naqshabandī, Jāmi' al-Ușūl fì al-Awliyā' (Surabaya: Maṭba 'ah al-Haramayn, tt), 87.
} 
kewalian kecil atau al-wilāyah al-sughrā (الْوَلَيَةِ الصُُْْرَي). Kewalian ini diperoleh dalam tingkat murāqabah ma iyah (اقلمراقبة (المعية) yaitu orang yang selalu merasakan kehadiran Allah swt dalam setiap keadaan dan tempat di manapun dia berada. ${ }^{50}$ Seorang yang sudah mencapai tingkat wali kecil ini diyakini semua sikap, perkatan dan putusannya adalah bayangan dari kehendak dan keputusan Allah swt, seperti dalam ungkapan $i d h$ al-sayru fì hādhā al-maqām yakūnu fi zilāli al-asmā' wa al-ṣifāt lidh̄̄ al- 'ulā

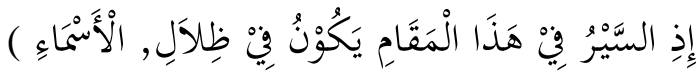
Karena perjalanan

pada maqam ini ada ia di dalam bayangbayang, segala asma' dan segala sifat bagi Tuhan Yang Maha Tinggi”. Sehingga dengan melalui konsep inilah lahir keyakinan seorang murid terhadap mahfüznya murhsid yang sudah menjadi wali. Mursyid yang disebut waliyan mursyidan tidak mungkin salah termasuk dalam membimbing muridnya karena sudah terjaga dari dosa karena limpahan karunia Allah swt terhadapnya dan setiap gerak langkahnya yang merupakan bayangan Tuhan.

Murāqabah ma'iyah sebagai tingkat kewalian paling rendah adalah

50 Murāqabah ma iyyah ini didasarkan kepada firman Allah Q.S al-Hadid [57]: 4.

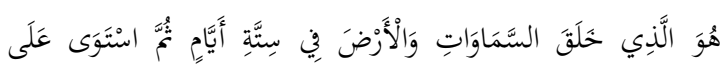

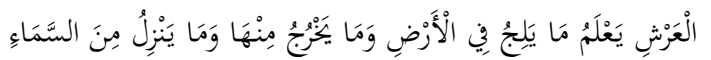

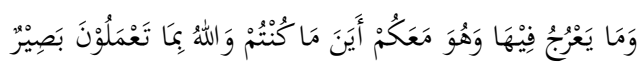

Artinya: "Dialah yang menciptakan langit dan bumi dalam enam masa; Kemudian Dia bersemayam di atas `Arsy Dia mengetahui apa yang masuk ke dalam bumi dan apa yang keluar daripadanya dan apa yang turun dari langit dan apa yang naik kepadanya. Dan Dia bersama kamu di mana saja kamu berada. Dan Allah Maha Melihat apa yang kamu kerjakan." juga diajarkan kepada murid atau sālik dengan tujuan untuk menenteramkan dan menciptakan ketenangan hati bagi seorang murid atau sālik. Hal ini dianalogikan perasaan damai dan tenang seseorang jika bersamanya ada seorang raja besar lagi kaya raya, atau perasaan tennag dan damai seorang pemuda jika ada seorang wanita yang cantik jelita selalu menemaninya. ${ }^{51}$ Hal itulah yang tercermian dalam ungkapan 'alayhim

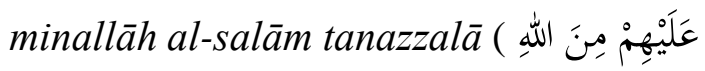
“' (السَّلالَُ تَنَزَّلاً daripada Allah ta 'álá salam yang turun ia”. Begitulah murāqabah ma 'iyah yang mampu melahirkan ketenangan dan kegembiraan. Sehingga, orang yang selalu tenang tidak pernah diliputi rasa takut dan sedih adalah orang yang telah sampai ke tingkat al-wilāyah al-suhgrá (kewalian kecil). ${ }^{52}$

Dalam bait di atas, Syaikh Ismā'îl al-Khālidī juga menjelaskan tentang hakikat kewalian. Di mana kewalian dimaksud adalah seseorang selalu merasakan kehadiran Allah swt. di manapun dia berada. Dia sudah bisa merasakan, bahkan melihat hal-hal yang tersembunyi dan ghaib dengan limpahan ilmu Allah swt. Dia menemukan Allah swt. dan kebesaran-Nya dalam wujud alam semesta. Kemanapun dia menghadap di situ dia menemukan Allah swt. $^{53}$

Inilah yang kemudian disebut karamah (الكرامة) berupa kemampuan luar bisa yang diberikan kepada manusia bisa yang terpilih melalui intensitas ubudiyah

51 Syekh H. Djalaluddin, Sinar Keemasan 2, Dalam Mengamalkan Keagungan Kalimah Laailaaha Illallah (Surabaya: Terbit Terang, tt), 35-38.

${ }^{52}$ Syofyan Hadi, Naskah al-Manhal al- 'Adhb li Dhikr al-Qalb, 63.

${ }^{53}$ Lihat naskah al-Manha, 14. 
dan riyādah yang sangat tinggi. Biasanya karamah datang tidak atas dasar keinginan atau pilihan yang bersangkutan, namun karamah adalah karena pilihan Allah semata. Biasanya seorang yang memperoleh karamah tidak akan pernah menceritakannya kepada siapapun, termasuk keluarga terdekat sekalipun. Cerita karamah seorang syaikh, mursyid atau orang salih ini baru berkembang setelah yang bersangkutan meninggal dunia dan diceritakan oleh orang terdekat, murid atau siapapun yang pernah melihat kelebihan syaikh atau mursyid tersebut. ${ }^{54}$

Seperti yang dijelaskan penulis dalam penelitian sebelumnya bahwa munculnya paham kewalian dalam tarekat Naqsyabandiyah Khālidiyah agaknya juga dipengaruhi oleh karekater perkembangan ajarannya yang dikenal sangat dekat dan seringkali menginisisasi dirinya dengan kekuasaan. Kewalian yang di dalamnya ada karāmah yang dimiliki oleh seorang syaikh tarekat akan dengan mudah memantapkan pengaruh dan melakukan legitimasi kekuasaan. $^{55}$ Oleh karena adanya pemahaman tentang kewalaian inilah, dalam bait lain Syaikh Ismā'îl alMinangkabawī menyatakan silsilah pengambilan ajaran zikir tarekat Naqshabandiyah Khalidiyah secara rohani kepada nabi Khidr as, seperti bait berikut.

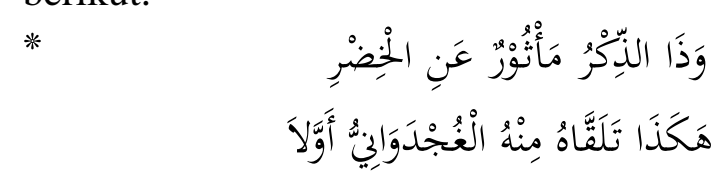

Barmula zikir ini diambil daripada nabi Allah khidir * demikianlah yang telah menerima akan dia daripadanya 'Abd

\footnotetext{
54 'Abdullāh ibn 'Alawī al-Haddād al-Haḍramī, Risālah Adab Sulūk al-Murid, 53.

${ }^{55}$ Syofyan Hadi, Naskah al-Manhal al- 'Adhb li Dhikr al-Qalb, 64.
}

al-Khāliq al-Ghujdawani pada mulamula $^{56}$

Dengan pengambilan silsilah tarekat Naqshabandiyah secara rohani oleh Syaikh 'Abd al-Khāliq alGhujdawānī kepada nabi Khaidr as. diduga kuat menjadi salah satu bukti adanya paham kewalian dalam ajaran tarekat Naqshabandiyah yang berkembang di Minangkabau. Bahkan, munculnya ajaran tentang sakralitas mursyid yang tidak boleh dibantah apalagi diprotes oleh murid sekalipun perbuatan sang mursyid salah menurut pandangan murid, kemungkinan bagian dari dampak paham kewalian dan karamah awliya' tersebut. ${ }^{57}$ Fenomena sakralitas mursyid yang kāmil mukammil serta ma'șūm (terjaga dari dosa) lagi karāmah ini diduga kuat memiliki keterkaitan yang sangat erat dengan pengambilan jalur silsilah keilmuan ajaran tarekat Naqshabandiyah yang dikembangkan Syaikh Ismā'îl alMinangkabawī yang terhubung langsung kepada nabi Khaidir as secara barzakhī. ${ }^{58}$

Dalam konteks ini menarik untuk dicermati bahwa dalam sumber-sumber awal tentang ajaran tarekat Naqshabandiyah tidak disebutkan pengambilan silsilah kepada nabi Khidir as melalui barzakhī tersebut. Dalam

\footnotetext{
${ }^{56}$ Naskah al-Manhal, 17.

${ }^{57}$ Lihatlah bagaimana kisah nabi Musa dan nabi Khidr diceritakan Allah swt. dalam al-Qur'an. Dalam cerita itu digambarkan bahwa apapun yang dilakukan oleh nabi Khaidr sebagai guru atau murshid bagi nabi Musa adalah benar dan tidak boleh diprotes. Sebuah sikap atau keputusan sang guru murshid sekalipun salah menurut ukuran murid, namun murid dalam hal ini nabi Musa as. tidak boleh bertanya apalagi membantahnya, sampai sang guru murshid memberitahukan sendiri rahasia perbuatannya itu. Lihat Q.S. al-Kahfi [18]: 65-82.

${ }^{58}$ Syofyan Hadi, Naskah al-Manhal al- 'Adhb li Dhikr al-Qalb, 64.
} 
silisilah tarekat Naqshabandiyah hanya dijelaskan bahwa tarekat ini berasal dari nabi Muhammad saw yang diajarkan kepada sahabatnya terus berlanjut ke generasi tābi'īn dan seterusnya kepada para syaikh tarekat Naqshabandiyah dan silsilah bersambungdan berlangsung tanpa terputus melalui kontak dan pertemuan yang bersifat fisik. ${ }^{59}$ Begitu juga, seperti halnya sudah penulis jelaskan dalam penelitian terdahulu bahwa dalam jalur silsilah syaikh tarekat Naqshabandiyah yang dikemukan oleh Muhammad Amīn al-Kurdī yang menjadi rujukan utama para pengikut ajaran tarekat Naqshabandiyah tidak menyebutkan adanya jalur silsilah kepada nabi Khidir as. Memang Muhammad Amin al-Kurdī membicarakan tentang silsilah yang bersifat barzakhī atau uways $\bar{\imath}$ yaitu mengambilan bai'ah melalui pertemuan secara batiniyah atau mimpi dari syaikh yang sudah lama wafat. Namun, tidak disebutkan bahwa 'Abd al-Khāliq alGhujdawan̄ termasuk syaikh tarekat Naqshabandiyah yang mengambil bai'ah dengan cara barzakhī atau uwaysī seperti disebutkan dalam teks al-Manhal ini. ${ }^{60}$ Agaknya penyebutan silsilah tarekat Naqshabandiyah secara barzakhi oleh 'Abd al-Khāliq al-Ghujdawan̄̄ kepada nabi Khidr as adalah keinginan Syaikh Ismā'̄ill al-Minangkabawī untuk menunjukan bukti bagaimana kewalian dan karāmah memang sudah pernah terjadi dan berlangsung dalam kehdiupan para syaikh tarekat Naqshabandiyah sebelumnya. Oleh karena itu, konsep kewalian (al-wilayāh) bukanlah suatu

59 Abbās Husain Bașri, al-Mużakkirah alZahabiyyah fi al-Tariqqah al-Naqshabandiyah ('Idpo: Awlad al-Ghanimi, 1996), 10.

${ }^{60}$ Lihat lebih lanjut. Muhammad Amīn al-Kurdī, Tanwīr al-Qulūb fì Mu'āmalat 'Allām al-Ghuyūb (Jeddah: al-Ḥarām ain, tt), 500-502. Lihat penjelasan ini dalam Syofyan Hadi, Naskah alManhal al-'Adhb li Dhikr al-Qalb, 65. kebohongan atau sesutau yang diadaadakan karena memang sudah ada yang mengalaminya.

Dalam teks Nazam juga disebutkan beberapa syaikh yang memiliki karamah dan kelebihan sebagai wali, seperti gambaran tang Shakyh Abdullāh al-Dahlawī yang mursyid tarekat di Jabal Qubays. Di mana disebutkan bahwa Syaikh Abdullah meninggal dalam kedaan duduk, dan tetap mengawasi murid-muridnya dan menunggu limpahan dari Tuhan, seperti bait berikut.

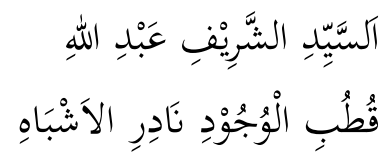

Al-Sayid al-Sharīf 'Abd Allāh * quṭub al-wujūd yang jarang umpamanya

*

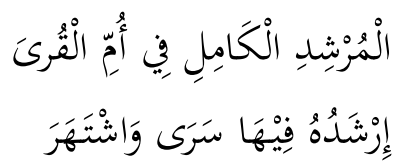

Mursyid yang kāmil pada Umm al-Qurā

* bimbingannya di sana telah berlaku dan masyhur

*

$$
\begin{aligned}
& \text { الْمُتَوَفََّّ جَالِسنًا مُرَاَِقِبا } \\
& \text { مُنْتَظرلا مِنْ رَبِّ مُوَاهِبَا }
\end{aligned}
$$

Yang wafat dalam kondisi duduk lagi mengawasi * sambil menunggu pemberian Tuhan $^{61}$

$$
\begin{aligned}
& \text { مُسْتَقْبْلاً لِلْكَعْبَةِ الْمُشَرَفَفْهُ } \\
& \text { قَبْلَ طُلُْعْ الْفَجْرِ يَوْمَ عَرَفَهْ }
\end{aligned}
$$

Menghadap ka'bah yang mulia * sebelum terbit fajar hari 'Arafah

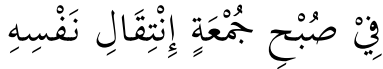

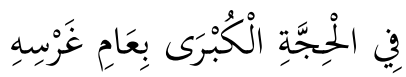

${ }^{61}$ Naskah Nazam, 2. 
Pada subuh Jum'at berpindah dirinya *

Pada haji akbar adalah tahun pemakamannya $^{62}$

Dalam bait di atas terlihat betapa Syaikh Abdullah al-Dahlawī diyakini oleh Syaikh Ismā'îl al-Minangkabawī sebagai mursyid yang telah mencapai taraf kewalian dan sekaligus telah memperoleh karāmah. Hal itu terlihat dari kematiannya yang dalam keadaan sedang duduk dan masih tetap mengawasi murid-muridnya. Seperti dalam ungkapan al-mutawaffā jālisan murāqiban (الْمُتَوَفََّّ جَالِسًا مُرَاََقِبَا) "Yang wafat dalam kondisi duduk lagi mengawasi”. Dalam gambaran kematian tersebut dijelaskan bahwa sepertinya Abdullah al-Dahlawī telah mengetahui waktunya karena dia penuh kesiapan menunggu pemberian Tuhan seperti ungkapan muntaziran $\min r a b b$

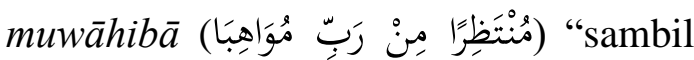
menunggu pemberian Tuhan". Bahkan, dia meninggal dalam posisi sangat siap dengan posisi tubuh yang sebelumnya sudah menghadap kiblat, seperti ungkapan mustaqbilan li al-ka'bati al-

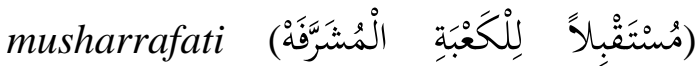
"Menghadap ka'bah yang mulia". Semua cerita tentang akhir kehidupan Syaikh Abdullah al-Dahlawī ini yang diceritakan oleh Syaikh Isma'il alMinangkabawi dalam bait-baitnya, adalah salah satu bukti ajarannya tentang adanya karāmah yang dimiliki oleh guru mursyid tarekat Naqshabandiyah ketika sudah mencapai derajat kewalian.

Dalam konsepsi kewalian dan karāmah ini, ditegaskan bahwa rohani guru mursyid disebutkan telah mencapai alam malakūt dan telah mampu mengetahui dan berkomunikasi dengan alam ghaib. Guru mursyid dengan

\footnotetext{
${ }^{62}$ Naskah Nazam, 3.
}

kebersihan dan cahaya rohani yang dimilikinya berkat latihan rohani yang selama ini dijalaninya, diyakini telah mampu melihat sesuatu yang oleh kebanyakan manusia tidak bisa dilihat atau dijangkau. Seperti yang digambarkan Syaikh Ismā‘īl alMinangkabaw $\overline{1}$ tentang rohani para syaikh tarekat Naqshabandiyah sebagaimana disebutkan dalam bait berikut.

*

$$
\begin{aligned}
& \text { وَذَاكَ الطَرِيََْةُ النَقْشَبَنْدِيَّةُ الْأَوَلَي }
\end{aligned}
$$

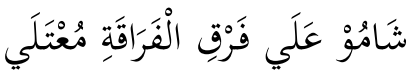

Barmula yang demikian itu ialah țarīqat al-Naqshabandiyah ialah țarīqat yang telah* naik mereka itu atas puncak segala bulan dan bintang ditinggikan ${ }^{63}$

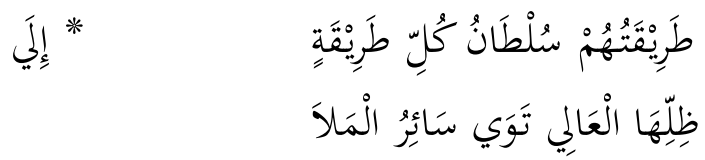

Barmula țarīqat mereka itu ialah raja bagi sekalian țarīqat * kepada naungnya yang amat tinggi bernaung sekalian makhluk

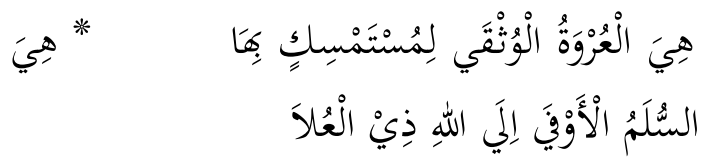

Ia lah sangkutan yang amat teguh bagi yang bergantung dangan dia itu* ialah tangga yang amat menaikan kepada Allah Yang Maha Tinggi

$$
\begin{aligned}
& \text { قَوَالِبُهُمْ فَوْقَ النُّرابِ تَعَلَّبَتْ }
\end{aligned}
$$

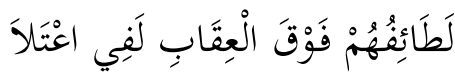

Barmula segala tubuh mereka itu di atas tanah jua berbalik-balik ia* barmula segala laț 'if mereka itu diatas pitala langit sungguhnya tinggi ${ }^{64}$

Dalam konteks karāmah ini, dijelaskan Syaikh Ismā'īl alMinangkabawi bahwa seorang syaikh, mursyid, atau wali yang sudah mencapai

\footnotetext{
${ }^{63}$ Naskah al-Manhal, 5.

${ }^{64}$ Naskah Nazam, 5.
} 
tingkat spiritual tertinggi secara fisik masih berada di bumi dan memang fisiknya terlihat seperti manusia kebanyakan. Aktifitas jasadiyah mereka tidak ada yang berubah dan berbeda, seperti tetap berjalan, makan, minum, tidur dan sebagainya. Seperti tergambar dalam ungkapan qawālibuhum fawqa al-

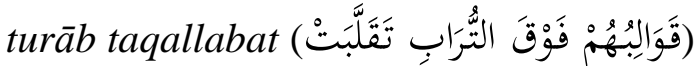

"Barmula segala tubuh mereka itu di atas tanah jua berbalik-balik ia". Akan tetapi, rohani mereka sebenarnya tidak lagi berada di bumi, namun sudah menjangkau alam rohani dan sudah berada di puncak tertinggi keberadaan alam semesta. Rohaninya telah mencapai alam malakūt yang tidak bisa dicapai oleh kabanyakan manusia biasa. Seperti dalam ungkapan latā'ifuhum fawqa al-

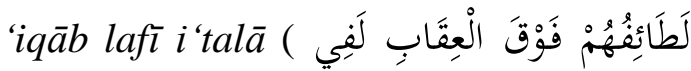
(اعتَلكَ (barmula segala laṭa'if mereka itu diatas pitala langit sungguhnya tinggi”.

\section{Kesimpulan}

Berdasarkan paparan di atas diketahui bahwa dalam beberapa konsep ajaran sufistik yang dikembangkannya di Nusantara, terutama dalam konteks ajaran tarekat Naqsyabandiyah Khalidiyah terlihat upaya Syaikh Isma'il al-Minangkabawi untuk melakukan inovasi, kreasi dan "lompatan" konsep tarekat yang berbeda dari konsep yang pernah dipelajarinya di Haramain dari tokoh-tokoh tarekat Naqsyabandiyah sendiri. Dalam konteks ini pula terlihat originalitas konsep sufistik yang dikembangkannya di Nusanatara yang boleh jadi disebabkan faktor sosial politik yang ada pada saat itu yang menuntutnya sedikit harus melakukan inprovisasi dalam merumuskan konsep tasawufnya. Pada sisi lain, justru ide-ide sufistiknya yang dianggap kelompok dogmatis formalitas (fuqaha) menyimpang inilah yang kemudian membuat Syaikh Isma'il alMinangkabawi mendapat tantangan hebat dari ulama pada masanya hingga harus kembali ke tanah suci untuk selamanya dan meninggal di sana.

\section{Daftar Pustaka}

Abdullah, Wan Mohd. Shaghir. Penjelasan Nazham Syair Shufi Syeikh Ahmad al-Fathani. Kulala Lumpur: Khazanah Fathiyah, 1993.

Abdullah, H.W. Muhd. Shaghir. Syeikh Ismāìl al-Minangkabawi Penyiar Thariqat Naqsyabandiyah Khalidiyah. Solo: Ramadhani, tt.

Abū al-Khayr, 'Abdullāh Mirdad. AlMukhtașar min Kitāb Nashr al-Nūr wa al-Zuhār fi Tarājim Afādil Makkah min al-Qarn al-'Āshir ilā al-Qarn al-Rābi' 'Ashar. Jeddan: 'Alam al-Ma'rifah, 1986.

Aceh, Abu Bakar. Pengantar Ilmu Tarekat: Uraian Tentang Mystik. Solo: Ramadhani, 1986.

Atjeh, Aboebakar. Pengantar ilmu Tarekat. Solo: CV. Ramadhani, 1985.

Azra, Azyumardi. Islam Nusantara, Jaringan Global dan Lokal. Bandung: Mizan, 2002.

Bașri, Abbās Husain. Al-Mużakkirah alZahabiyyah fi al-Țarīqah alNaqshabandiyah. 'Idpo: Awlad alGhanimi, 1996.

Al-Bakrī, Abū al-Fayḍ 'Abd al-Sattār ibn 'Abd al-Wahhāb. Fayd alMālik al-Wahhāb al-Muta'āli bi Abnā'i Awā'il al-Qarn al-Thālith 'Ashar wa al-Tawāli Jilid 1. Makkah al-Mukarramah: Maktabah al-Asadiyah, 2009.

Bruinessen, Martin van. "After The Days of Abu Qubays : Indonesian Tranformations of The 
Naqsyabandyya-Khalidiya",

Journal of The History of Sufism 5 (2007).

Bruinessen, Martin Van. Tarekat Naqshabandiyah di Indonesia, Survey Historis Geografis dan Sosiologis. Bandung: Mizan, 1994.

Demirpolat, Anzavur. "Sosio-Cultural Dynamics of Muridizm Movement in Caucasia, Journal of Ilahiyat Fakultesi Dergisi, 12:1 (2007).

Al-Dīn, Jalāl. Rahasia Mutiara alTarīqah al-Naqshabandiyah. Bukittinggi, Partai Politik Tarekat Islam (PPTI), 1950.

Djalaluddin, Tiga Serangkai: Mengutuki Buku Fatwa Tharikat Naqsjabandijah \& Lima Serangkai Mentjari Allah dan Menemukan Allah Sesuai Dengan Intan Berlian/Lukluk dan Mardjan tharikat Naksjabanijah. Djakarta: Sinar Keemasan, 1964.

Djalaluddin Syekh H.. Sinar Keemasan 2, Dalam Mengamalkan Keagungan Kalimah Laailaaha Illallah. Surabaya: Terbit Terang, tt.

Gammer, Moshe. "The Beginnings of The Naqshabandiyya in Dāghestān and The Russian Conquest of The Caucasus" Jornal of Die Welt des Islams, New Series, Vol. 34, Issue 2 (Nov 1994).

Hadi, Syofyan. Naskah al-Manhal al'adhb li-dhikr al-qalb: Kajian atas Dinamika Perkembangan Ajaran Tarekat Naqshabandiyah alKhâlidiyah di Minangkabau. Jakarta: Lembaga Studi Islam Progresif, 2011.

Hadi, Syofyan. Sastra Sufistik Nusantara: Orisinalitas Gagasan dan Stilistika Karya Syaikh Isma'il al-Minangkabawi.

Jakarta:
Lembaga Studi Islam Progresif, 2014.

ibn 'Ajībah, 'Abdullāh Aḥmad. Mi 'rāj al-Tashawwuf ilā Haqā'iq alTașawwuf. Al-Maghribī: Dār alBayḍā', tt.

Al-Haḍramī, 'Abdullāh ibn 'Alawī alHaddād. Risālah Adab Sulūk alMurid. Al-Qāhirah: Dār al-Ḥāwī li al-Ṭibā'ah wa al-Nashr, 1994.

Kemper, Michael. "Khalidiyah Networks in Daghestan and The Question Jihad, Jornal of Die Welt des Islams, New Series, Vol. 42, Issue 1 (2002).

Al-Khālidī, Muhammad al-Amīn. "Naskah Ajaran Tarekat Naqshabandiyah Khalidiyah", Koleksi surau Muhammad alAmīn Kinali-Pasaman.

Al-Khālidī, Muḥammad al-Amīn. "Naskah Ajaran Tarekat Naqshabandiyah Khalidiyah" Koleksi surau Muhammad alAmīn Kinali-Pasaman.

Al-Khālidī, Muḥammad Husayn ibn 'Abd al-Șamad. "Naskah Nahjat al-Sālikīn wa-Bahjat alMaslakīn,".

Al-Khalidi, Khalifah Rajab. Naskah Ilmu Segala Rahasia.

Al-Khālid̄̄, 'Abd al-Maj̄̄id Muḥammad AL-Khānī. Al-Sa'ādah alAbadiyah fì Mā Jā'a bihi alNaqshabandiyah. Dimashqa: Maṭba'ah al-Iṣlāḥ, 1313 H.

Knysh, Alexander. "Sufism as an Explanatori Paradigm: The Issue of The Motivations of Sufi Resistance Movement in Western and Russian Scholarship, Journal of Die Welt des Islams, New Series, Vol. 2, Issue 2 (2002). 
Al-Kurdī, Muhammad Amīn. Tanwīr alQulūb fì Mu'àmalat 'Allām alGhuyūb. Jeddah: al-Ḥarām ain, tt.

Laffan, Michael. The Makings of Indonesian Islam: Orientalism and Narration of a Sufi Past. New Jersey: Princeton University Press, 2011.

Al-Naqshabandī, Diyā’ al-Dīn Aḥmad Muștafá al-Khamashkhanawī. Jāmi' al-Ușūl fì al-Awliyā'. Surabaya: Maṭba'ah al-Haramayn, tt.

Nasr, Seyyed Hossein. dkk (Ed). Warisan Sufi, Warisan Sifisme Persia Abad Pertengahan (11501500)Jilid II. Depok: Pustaka Sufi, 2003.

Nasr, Seyyed Hossein. The Garden of Truth: The Vision and Promise of Sufism, Islam's Mystical Tradition, diterjenahkan oleh Yuliani Liputto, The Garden of Truth: Mereguk Sari Tasawuf. Bandung: PT. Mizan Pustaka, 2010.

Pudjiastuti, Titik. Naskah dan Studi Naskah. Bogor: Akademia, 2006.

Sa'id, H.A.Fuad. Hakikat Tarikat Naqshabandiyah. Jakarta: PT. alHusna Zikra, 2001.

Al-Sakandarī, Ibn 'Ațā'illāh. Al-Hikam. Mișr: Maktabah wa-Mațba'ah Muhammad 'Alī Șābih waAwlādih, tt.

Schrieke, B.J.O. Pergolakan Agama di Sumatera Barat; Sebuah Sumbangan Bibliografi. Jakarta: Bharatara, 1973.

Solihin, M. Melacak Pemikiran Tasawuf di Nusantara. Jakarta: Raja Grafindo Persada, 2005.

Sunyoto, Agus. Sulūk Abdul Jalil, Perjalanan Sufi Syaikh Siti Jenar
Volume 2. Yogyakarta: Pustaka Sastra Lkis, 2005.

Sunyoto, Agus. Suffatni, Retno. Sulūk Malang Sungsang: Konflik dan Penyimpangan Ajaran Syaikh Siti Jenar. Yogyakarta: LKiS Pelangi Aksara, 2004.

Tim Redaksi Majalah Detik, "Sufi Metropolis", Majalah Detik, Edisi 89 (12-18 Agustus, 2013).

Ya'qub, Khalīfah Syaikh. Naskah Ajaran Tarekat Naqshabandiyah Khalidiyah. 